\title{
ONLINE POLITICAL COMMUNICATION OF YOUTH FROM RUSSIAN MEGAPOLISES
}

\section{Olga V. Popova}

St. Petersburg State University. Saint Petersburg, Russia. Email: o.popova[at]spbu.ru

\begin{abstract}
Youth remains one of the most active groups of Internet users. The purpose of the study is to identify the features of the use of various social networks, Internet channels and messengers in online political communication of young people from Russian megacities. The research paper presents the results of an online survey of this socio-demographic group conducted in January 2021 among roughly 1700 respondents from 17 Russian megacities as well as the results of an expert survey dated January 2021, namely, nonstandardized expert interviews with 21 experts, including scholars, political technologists, government officials, members of political organizations and civil activists. Every fourth young respondent spends over 8 hours in the Internet space daily with about $43 \%$ of all young people spending from 4 to 8 hours. Social networks such as VKontakte (91.4\%), Instagram (70.6\%), YouTube Internet channel (74.9\%), WhatsApp (66.4\%) and Telegram $(59.2 \%)$ are most in demand. The interest in Tik Tok is gradually growing (38.8\%). Experts believe that the promising channel of online political communication with the aim of online political mobilization is the social network Clubhouse, which allows group voice chats and a strict selection of group members, but does not allow direct recording. Only every fourth representative of young people shows a high interest in the political situation. About $45 \%$ use Emoji to assess posts on a political topic, but only every fourth respondent gives comments and discusses political problems. Every fourth representative of young people does not take any political actions in the online space.
\end{abstract}

\section{Keywords}

Russian youth; megapolis; interest in politics; political communications; online communication; internet channels; messengers; social networks; political action on the Internet; Internet activism; online political participation 


\section{ПОЛИТИЧЕСКАЯ ОНЛАЙН-КОММУНИКАЦИЯ МОЛОДЕЖИ РОССИЙСКИХ МЕГАПОЛИСОВ}

Попова Ольга Валентиновна

Санкт-Петербургский государственный университет. Санкт-Петербург, Россия.

Email: o.popova[at]spbu.ru

\section{Аннотация}

Молодежь остается одной из наиболее активных групп пользователей контента интернет-пространства. Цель исследования - выявить особенности использования в политической онлайн-коммуникации различных социальных сетей, интернет-каналов и мессенджеров молодежью из российских мегаполисов. В статье приведены данные онлайн-опроса этой социально-демографической группы (анкетирование, январь 2021 г.). Выборка составила 1700 респондентов из 17 российских мегаполисов. В статье нашли частичное отражение результаты экспертного опроса (нестандартизованное экспертное интервью, 21 эксперт из числа ученых, политтехнологов, представителей властных структур и политических организаций, гражданских активистов; январь 2021 г.). Каждый четвертый молодой респондент проводит в интернет-пространстве свыше 8 часов ежедневно, около 43\% молодежи - от 4 до 8 часов. Наиболее востребованы у молодежи социальные сети ВКонтакте (91,4\%), Instagram (70,6\%), интернет-канал YouTube (74,9\%), мессенджеры WhatsApp (66,4\%) и Telegram (59,2\%). Постепенно растет интерес к Tik Tok (38,8\%). Уровень доверия к используемым онлайн-источникам информации высокий. Эксперты называют в качестве перспективного канала политической онлайн-коммуникации с целью политической онлайнмобилизации социальную сеть Clubhouse, которая допускает групповые голосовые обсуждения, обеспечивает жесткую селекцию участников группы, но не позволяет напрямую осуществлять запись, что наиболее удобно представителям несистемной оппозиции. Две трети молодежи интересуются онлайн-материалами о досуге и хобби, новостями города, региона, страны, информацией профессионального и учебного характера. Для каждого пятого респондента важны проблемы экологии, возможности поддержки политических организаций и их лидеров, сведения об участии в политических, в том числе протестных, мероприятиях. Лишь каждый четвертый представитель молодежи проявляет высокий интерес к политической ситуации. Около 45\% используют эмодзи для оценки постов на политическую тему, но лишь каждый четвертый респондент дает комментарии и обсуждает политические проблемы. Каждый четвертый представитель молодежи не предпринимает никаких политических действий в онлайнпространстве.

\section{Ключевые слова}

российская молодежь; мегаполис; интерес к политике; политическая коммуникация; онлайн-коммуникация; интернет-каналы; мессенджеры; социальные сети; политические онлайн-действия; уровень политической интернет-активности

Это произведение доступно по дицензии Creative Commons «Attribution» («Атрибуция») 4.0 Bceмирная 


\section{ВВЕДЕНИЕ}

Ставший рутинной частью повседневной жизни миллионов людей интернет прочно вошел в перечень наиболее актуальных объектов исследования целого ряда общественных наук. Широта тем этих научных проектов исключительно вариативна: они охватывают проблемы становления новых цифровых форм демократии (Contucci, Omicini, Pianini, \& Sîrbu, 2019), расширения зоны реальной политики в интернет-пространстве (Добринская, 2018, сс. 52-70), позиционирования в онлайн-пространстве институтов власти, политических организаций и социальных движений (Рябченко, Катермина, Гнедаш, \& Малышева, 2018, сс. 139-162), оценки современных форм политического онлайн-участия (Deth, 2014) и их возможных последствий (Исакова, \& Коротышев, 2018, сс. 41-55; Михайленок, 2019, сс. 12-21). Ряд ученых сосредоточен на изучении роли социальных сетей в политической коммуникации (Юй, 2021, сс. 149-158), практик политической онлайн-коммуникации и выявлении наиболее эффективных технологических приемов воздействия на массовое сознание пользователей интернет-каналов, мессенджеров и социальных сетей (Ачкасова, \& Мельник, 2016; Быков, 2013; Дзялошинский, 2012).

Исследования механизмов формирования общественного мнения в массмедиа (Dijk, 2013) и выявления лидеров политического влияния в онлайн-пространстве (Barbera, Casas, \& Nagler, 2019, pp. 883-901; Davis, 2009) прочно завоевывают исследовательское поле в современных научных проектах. Одним из актуальнейших направлений исследований выступают механизмы распространения информации о протестных социальных движениях (Klandermans, 2014, pp. 1-22) в различного рода мессенджерах, позволяющих координировать действия их участников, привлекать новых сторонников (Gleason, 2013, pp. 966-982), эффективно выполнять задачи онлайн-мобилизации (Авзалова, 2020, сс. 2866-2871). Решение конкретных, подчас достаточно «узких» исследовательских вопросов, связанных с микроуровнем изучения политической онлайн-коммуникации (Evans, 2017; Володенков, Артамонова, 2020, сс. 188-196), имеют высокую научную ценность, поскольку позволяют уловить только намечающееся изменение практик реагирования аудитории на информацию в сетевом пространстве.

Пандемия COVID-19 оказала серьезнейшее влияние на социальные и политические процессы в современном мире. Ситуация локдауна привела в том числе и к временному «политическому затишью» - снижению публичной протестной активности (Безрукова, 
2020, сс. 58-62), которая может проявить себя с неожиданной силой в достаточно непредвиденные моменты. Роль социальных сетей в протестном политическом движении в современных условиях высока (Малькевич, 2020, сс. 35-42), а потому наряду с анализом политических действий представителей различных интернет-сообществ (Theocharis, 2015, pp. 1-14; Бродовская, Домбровская, \& Синяков, 2015, сс. 80-87) ученые обращают все более пристальное внимание на протестный потенциал публичного поведения различных групп и сообществ, в том числе и молодежи (Истягина-Елисеева, Бариеникова, \& Болдырева, 2020, сс. 12-20; Палагичева, 2019, сс. 218-231; Соколов, \& Палагичева, 2020, сс. 266-297; Шаповалова, 2015, сс. 148-151; ХвыляОлинтер, 2016, сс. 104-109), поскольку он может проявиться не только в формальных видах интернет-активизма, но и трансформироваться в варианты гражданского политического активизма офлайн. На наш взгляд, показатели вариативности процессов, связанных с политическими офлайн- и онлайн-коммуникациями и поведением молодежи из мегаполисов, настолько высоки в настоящее время, что они заслуживают дополнительного эмпирического анализа.

Объектом изучения в данной статье выступает молодежь российских мегаполисов, а предметом - практики политической онлайнкоммуникации этой социально-демографической группы. Молодежь - социально-демографическая группа в возрасте от 14 до 30 лет представляет для политологов и политических социологов исключительно важный объект для анализа, поскольку позволяет не только выявить систему ценностей, политических предпочтений, моделей политического поведения, особенностей вторичной политической социализации и ресоциализации новых поколений, но и сделать прогнозы относительно изменения характера публичных политических процессов в краткосрочной и среднесрочной перспективах. Выбор данного объекта предопределен как высокими показателями включенности молодежи в коммуникацию в интернет-пространстве, так и достаточно высоким потенциалом ее гражданского и протестного политического активизма.

Цель исследования - выявление актуального состояния использования молодежью различных интернет-порталов, социальных сетей и мессенджеров с точки зрения их использования политическими акторами для распространения определенной политической информации, формирования массовых политических взглядов и определенных политических действий в интернет-пространстве. 


\section{МЕТОДЫ}

В последние годы отечественные политологи все более активно включают в свой арсенал исследовательских средств такой инструмент, как онлайн-опросы. Преимущества современных онлайн-исследований, особенно в условиях пандемии, очевидны. Они позволяют получить доступ к труднодоступным респондентам, значительно повышают технологичность процедуры сбора информации, включая пространственный охват объектов анализа, возможность оперативного сбора информации, максимально приближенного к оказывающему влияние на массовое сознание событию, что может быть зафиксировано только в предельно короткий срок. Технологические преимущества онлайн-анкетирования также не вызывают сомнений: полностью снят эффект влияния анкетера на респондента, минимизированы риски ошибок ввода данных, предельно легко осуществляется контроль над выборкой. Также достаточно высокой оказывается внутренняя «конструктная» валидность онлайн-анкеты.

Раньше исследователи писали о предельном объеме онлайнанкеты в 7-12 вопросов, однако на сегодняшний день опросник в 25-30 вопросов оказывается вполне приемлемым, а количество не заполненных до конца в ходе опросов онлайн-анкет лишь незначительно превышает количество прерываемых уличных интервью. Риски нарушения требования внешней валидности выводов при проведении онлайн-опроса молодежи снимаются за счет особенностей стиля жизни и объема проводимого этой когортой в интернет-пространстве времени. В отношении молодежи почти не проявляются методические проблемы, снижающие активность заполнения респондентами онлайн-анкет. Алгоритм построения онлайн-анкеты в принципе аналогичен «бумажной» анкете; сложности могут создавать, скорее, попытки обеспечения репрезентативности в исследовании различных возрастных групп, однако в конкретном исследовании подобной проблемы не возникло. Осуществлялся жесткий контроль за квотами.

Эмпирическое исследование жителей российских мегаполисов в возрасте 14-30 лет было проведено методом онлайн-анкетирования в январе-начале февраля 2021 г. В выборку были включены следующие российские мегаполисы (15 официальных и два фактических): Москва, Санкт-Петербург, Новосибирск, Екатеринбург, Нижний Новгород, Казань, Челябинск, Омск, Самара, Ростов-на-Дону, Уфа, Красноярск, Пермь, Воронеж, Волгоград, Краснодар и Саратов. Объем выборки 1700 респондентов; выборка квотная, несвязанная с контролем по признакам пола (юноши - 52,3\%, девушки - 47,7\%), возраста (квотировались 3 возрастные подгруппы: 14-17 лет, 18-24 года, 25-30 лет; 
эти группы составили соответственно 30\%, 40\% и 30\%), уровня образования (обладатели начального, неполного среднего, полного среднего и средне-специального образования составили 58,8\%, незаконченного высшего и высшего - 41,2\%) и мегаполиса проживания (по 100 респондентов от каждого из 17 российских мегаполисов). Онлайн-анкета создана с помощью сервиса https://anketolog.ru, обработка данных осуществлялась в статистическом пакете SPSS Statistics 24.0.

В ходе исследования были получены данные о продолжительности нахождения молодежи в интернет-пространстве, предпочтительные для этой когорты мессенджеры, социальные сети и сервисы, а также уровень доверия к ним, приоритетные темы интереса, предпочтительный способ получения политической информации, уровень интереса к политической жизни в России. Выявлены уровень интереса в онлайн-пространстве к различным темам-мотиватиорам политического протеста, лидеры общественного мнения для молодежи в интернет-пространстве. Отдельный блок вопросов касался политического активизма в интернет-пространстве, представлений молодежи о репертуаре приемлемых и реальных политических практик онлайн и офлайн. Были выявлены факты участия в протестных политических мероприятиях за последний год, отношение как к несанкционированным акциям протеста, так и к людям, участвующим в них, а также представления о мотивации протестного политического поведения. Кроме того, был проведен анализ смысложизненных и политических ценностей молодежи мегаполисов, выявлена самооценка их политических взглядов и представлений о необходимых принципах организации жизни в государстве. В результате проведенного анализа были смоделированы варианты «потребления» молодежью политической информации, осуществления политической коммуникации и онлайнмобилизации, дана количественная оценка этих групп. Кроме того, выявлены мегаполисы с наиболее высоким потенциалом политического протеста молодежи.

В части характеристики возможностей использования различных интернет-каналов, мессенджеров и социальных сетей для политической онлайн-мобилизации будут представлены оценки экспертов. Экспертный опрос (нестандартизованное интервью) проводился онлайн с видеозаписью в Zoom в феврале 2021 г.; все видеозаписи интервью с экспертами прошли последующую полную расшифровку и подверглись процедуре дискурс-анализа. Объем выборки 21 эксперт (18 отечественных и 3 зарубежных, занимающихся непосредственно анализом особенностей политической онлайн-коммуникации и протестного движения в России), которые представили корпус 
ученых-политологов, политтехнологов (в том числе специализирующихся на интернет-технологиях), представителей власти, политических активистов (представляют системную и несистемную оппозицию). Продолжительность интервью составляла от 1 часа до 1 часа 40 минут.

Гайд нестандартизованного интервью позволил выявить представления экспертов о социально-демографических, статусных, мотивационных, идеологических и т.д. особенностях российской молодежи из мегаполисов, интересующейся в интернете политической информацией, в частности, темой политического протеста. Интервью касалось вопросов мотивации интереса молодежи к теме протестов, способности этой социально-демографической группы увидеть объективные проблемы современной России, которые в наибольшей степени связаны с возможным проявлением политического протеста. Были выявлены организации, движения, политические лидеры и лидеры общественного мнения, которые оказывают в настоящее время наибольшее влияние на массовое сознание молодых жителей мегаполиса. Эксперты дали исключительно ценную информацию об особенностях использования различных мессенджеров, социальных сетей, каналов в интернете для формирования определенного видения молодежью политической ситуации, для агитации и мобилизации на определенные публичные действия. Кроме того, была дана характеристика особенностям политической коммуникации молодежи онлайн, используемым технологиям и приемам онлайн-мобилизации, стратегиям распространения информации и моделям координации действий протестных групп и активистов. Эксперты предложили свое видение роли властных элит в изменении интенсивности неконвенциональной активности молодежи и трендов трансформации уровня протестных настроений.

Особенности экспертных интервью и целесообразность их применения в политологических исследованиях определяется как возможностью получить высокоточную, уникальную по своей полноте (в том числе и инсайдерскую) информацию от квалифицированных специалистов в обсуждаемом вопросе или «ключевых информаторов», не только глубоко погруженных в тему обсуждения, но и способных делать прогнозы на основе своих знаний. Специфика использования экспертных интервью заключается в возможности не только проверить выявленные в ходе массовых опросов или анализа с помощью техник работы с документами закономерности, но и выяснить скрытые тенденции развития политических процессов, которые только начинают зарождаться и формироваться. 
Применение нестандартизованного экспертного опроса в дополнение к массовому является хорошо известной, методически надежной процедурой сочетания качественных и количественных методов, позволяющей получить дополнительные сведения по интересующим исследователей вопросам. Если в ходе обработки данных онлайнопроса молодежи были получены количественные параметры политической онлайн-коммуникации, то в рамках экспертного опроса были уточнены особенности предпочтений выбора конкретных инструментов политической онлайн-коммуникации (и, как следствие, политической онлайн-мобилизации этой группы).

\section{ТЕМАТИКА И КАНАЛЫ ПОЛИТИЧЕСКОЙ ОНЛАЙН- КОММУНИКАЦИИ МОЛОДЕЖИ}

Молодежь российских мегаполисов проводит в интернетпространстве значительное количество времени: от 4-х до 8 часов $42,7 \%$, более 8 часов - 25,7\%, от 2 -х до 4 -х часов $-24,5 \%$. Только $5,0 \%$ молодых жителей российских мегаполисов тратят на пребывании в онлайн-пространстве менее 2-х часов ежедневно.

Безусловным лидерами с точки зрения широты охвата молодой аудитории и регулярности использования молодежью российских мегаполисов различных онлайн-площадок выступают ВКонтакте (91,4\%), YouTube (74,9\%), Instagram (70,6\%), WhatsApp (66,4\%) и Telegram (59,2\%). Постепенно набирает популярность Tik Tok $(38,8 \%)$ и ЯндексДзен (14,0\%), но теряет ее у молодежи Viber (25,0\%). Уровень интереса молодежи российских городов-миллионников к мессенджерам и сетям Twitter (11,7\%), Facebook (10,8\%), «Одноклассники» $(10,1 \%)$ и Skype $(8,5 \%)$ остается традиционно невысоким: только каждый девятый молодой житель российских мегаполисов использует их (Таблица 1).

Судя по полученным статистически значимым коэффициентам корреляции, характер связи между предпочитаемыми для использования каналами, сетями и мессенджерами и уровнем доверия им можно определить как функциональную зависимость: при фактическом отсутствии ограничений доступа к этим системам использование конкретного канала коммуникации порождает дополнительное доверие ему за счет эффекта привыкания (рутинности). 


\begin{tabular}{|c|c|c|c|c|c|c|c|}
\hline \multirow{2}{*}{$\begin{array}{c}\text { Канал получения } \\
\text { информации и } \\
\text { коммуникации }\end{array}$} & \multirow{2}{*}{$\begin{array}{c}\text { Регулярно } \\
\text { используют }\end{array}$} & \multicolumn{6}{|c|}{ Уровень доверия } \\
\hline & & 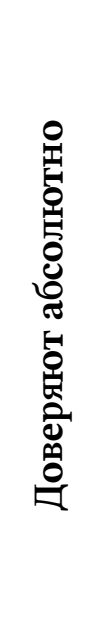 & 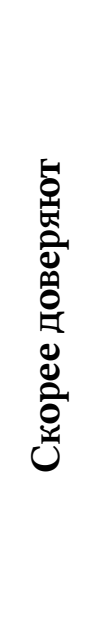 & 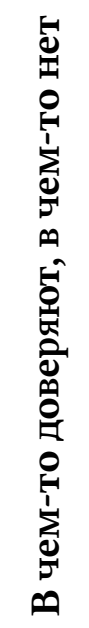 & 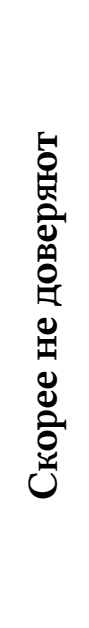 & 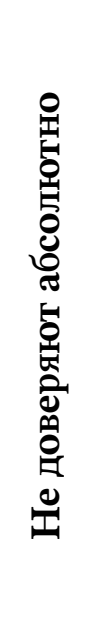 & 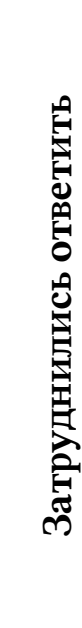 \\
\hline 1. ВКонтакте & 91,4 & 16,6 & 21,0 & 37,0 & 10,9 & 11,5 & 2,9 \\
\hline 2. Мой мир & 3,5 & 3,6 & 6,4 & 9,8 & 10,3 & 20,5 & 49,4 \\
\hline 3. Одноклассники & 10,1 & 5,9 & 9,8 & 12,8 & 12,1 & 23,5 & 35,9 \\
\hline 4. Телетайп & 0,9 & 2,3 & 2,7 & 5,5 & 5,9 & 15,4 & 68,2 \\
\hline 5. Яндекс-Дзен & 14,0 & 5,3 & 13,5 & 19,4 & 10,4 & 14,3 & 37,2 \\
\hline 6. Facebook & 10,8 & 5,7 & 16,4 & 19,9 & 9,8 & 14,8 & 33,5 \\
\hline 7. Flickr & 0,5 & 2,1 & 3,1 & 6,2 & 5,6 & 14,1 & 69,0 \\
\hline 8. Instagram & 70,6 & 18,1 & 27,2 & 30,1 & 8,6 & 8,4 & 7,6 \\
\hline 9. Linkedln & 1,4 & 3,1 & 5,1 & 7,2 & 5,7 & 11,8 & 67,1 \\
\hline 10. Skype & 8,5 & 10,6 & 22,2 & 19,0 & 7,1 & 9,6 & 31,5 \\
\hline 11. Telegram & 59,2 & 30,8 & 32,2 & 17,7 & 3,9 & 4,3 & 11,1 \\
\hline 12. Tik Tok & 38,8 & 15,3 & 14,8 & 18,5 & 8,4 & 16,4 & 26,6 \\
\hline 13. Tumblr & 1,6 & 3,2 & 4,2 & 7,8 & 6,2 & 13,0 & 65,7 \\
\hline 14. Twitter & 11,7 & 7,4 & 13,5 & 17,8 & 7,0 & 13,4 & 41,0 \\
\hline 15. Viber & 25,0 & 10,6 & 17,3 & 17,5 & 9,3 & 12,6 & 32,6 \\
\hline 16. WhatsApp & 66,4 & 20,2 & 26,3 & 23,6 & 9,9 & 9,6 & 10,4 \\
\hline 17. YouTube & 74,9 & 27,3 & 29,6 & 25,7 & 3,9 & 4,9 & 8,5 \\
\hline
\end{tabular}

Таблица 1. Регулярное использование молодежью мегаполисов различных интернет-каналов, социальных сетей и мессенджеров и доверие им (\% от числа опрошенных). Вопрос: «Какими мессенджерами, социальными сетями и сервисами Вы пользуетесь регулярно (не реже нескольких раз в неделю) в настоящее время? (Отметьте все варианты, которые относятся к Вам)» Вопрос: «Каким мессенджерам, социальным сетям и сервисам Вы доверяете, а каким не доверяете? (Пожалуйста, дайте ответ по каждой строке)» 
Предпочтения способа получения молодежью новостей четко делятся практически пополам между новостными лентами (42,8\%) и информационными ресурсами, на которые получатель информации подписан $(37,6 \%)$ (Таблица 2). Стоит обратить внимание на то, что через авторские экспертные сайты, каналы, блоги предпочитают получать новости 15,4\% городской молодежи; показатель этот важен, поскольку в два раза больше респондентов (около 33\%) заявили, что для них есть исключительно авторитетные персоны среди блогеров, чье мнение в оценке социальных процессов и политических событий исключительно важно и чья точка зрения практически не подлежит сомнению. Судя по всему, авторские каналы и блоги выполняют для молодежи не только экспертную функцию, но и функцию информационного сита, актуализирующего или делающего «невидимым» определенные политические события.

$\begin{array}{lc}\text { В новостной ленте } & 42,8 \\ \text { Через информационные ресурсы, на которые подписаны } & 37,6 \\ \text { Через авторские экспертные сайты, каналы, блоги } & 15,4 \\ \text { Другое } & 1,6 \\ \text { Затрудняюсь ответить } & 2,5 \\ \text { Итого } & 100,0\end{array}$

Таблица 2. Предпочтительный способ получения молодежью мегаполисов новостной информации онлайн (\%). Вопрос: «Какой способ получения новостной информации онлайн для Вас наиболее предпочтителен?»

От $60 \%$ до 68\% молодежи целенаправленно ищут в интернете инфформацию о досуге и хобби, узнают о новостях государства, региона и своего города, изыскивают необходимые им сведения для решения учебных или профессиональных задач (Таблица 3). При этом только каждого третьего молодого жителя мегаполиса интересуют вопросы, связанные с социальными проблемами своих сограждан и способами их разрешения. Еще меньше (от 19,6\% до 22,6\%) доля тех представителей молодежи, которых волнует информация о политических мероприятиях, решении экологических проблем или поддержке политических лидеров, движений или организаций. 

политических групп, движений, партий

Таблица 3. Интересующие молодежь мегаполисов темы в интернете (\%) Вопрос: «Какими темами в социальных сетях, мессенджерах и интернет-каналах Вы интересуетесь в первую очередь? (Отметьте все варианты, которые относятся $\kappa$ $B a \mathrm{M}) »$

Как показал опрос, политической жизнью в России очень интересуются 22,4\% молодежи в городах-миллионниках, лишь в некоторой степени - 58,5\% респондентов, совсем не интересуются 13,8\%, затруднились ответить на этот вопрос 5,4\%.

При этом полученная в ходе исследования информация о фиксации внимания достаточно большой доли молодежи на материалах, содержащих призывы к политической борьбе, показывает определенную возможность привлечения этой возрастной когорты к протестным действиям. Отметим, что совершенно нечувствительным к теме призыва к политической борьбе, к политическим протестам является каждый четвертый молодой житель мегаполиса (24,9\% респондентов заявили, что они такой информации в интернете или мессенджерах не видели или не обращали на нее свое внимание), еще 4,4\% затруднились ответить что-либо определенное по этому поводу.

Данные таблицы 4 показывают не степень распространенности в интернет-пространстве материалов на определенную тематику, а степень внимания к ней молодежи. Наиболее чувствительна молодежь к теме несправедливых или незаконных действий властей $(42,8 \%)$; этот показатель коррелирует с выбором молодежью ценности справедливости как наиболее значимой для себя (43,8\%). Чуть меньше доля респондентов (40,5\%), которые чувствительны к теме борьбы с коррупцией. В пределах 28-30\% молодежи обращают внимание на материалы 
о нарушении социальных прав граждан и прав избирателей во время предвыборной кампании и голосования. Необходимость борьбы с цензурой в СМИ и в онлайн-пространстве осознает $18 \%$ молодежи; борьба против ущемления прав меньшинств очевидна для менее чем 9\% респондентов. Последний показатель тем более примечателен, что женщины как социальная группа (не по количеству!) относятся к меньшинствам, равно как некоторые этнические общности, мигранты и сексуальные меньшинства. Судя по всему, в качестве нуждающейся в дополнительной защите группы молодежь воспринимает преимущественно последнюю из названных выше.

Обращали в Интернете внимание на призывы к борьбе против 42,8 незаконных/несправедливых решений властей

Обращали в Интернете внимание на призывы к борьбе с коррупцией 40,5

Обращали в Интернете внимание на призывы к борьбе против ущемления 29,5 социальных прав граждан

Обращали в Интернете внимание на призывы к борьбе против нарушений 27,8 на выборах

Обращали в Интернете внимание на призывы к борьбе против цензуры в 18,0 СМИ (включая Интернет)

Обращали в Интернете внимание на призывы к борьбе против ущемления 8,6 прав меньшинств

Таблица 4. Внимание молодых жителей мегаполиса к протестной тематике в Интернете (\%). Вопрос: «Если Вы сталкиваетесь в социальных сетях или интернете в целом с сообщениями, призывающими к участию в протестных акциях политического характера, какой тематике они обычно посвящены? (можно выбрать не более 3 вариантов ответа)»

«Общим местом» в рассуждениях как представителей научного сообщества, так и политиков и активных представителей гражданского общества о молодежи стали представления о ее высокой политической онлайн-активности, особенно о людях, проживающих в мегаполисах. Однако, как показал опрос, этот показатель нельзя признать высоким.

Каждый третий представитель молодежи из городов-миллионников $(35,6 \%)$ не предпринимает вообще никаких действий в интернетпространстве, которые могут быть оценены как политические (Таблица 5). За прошедший год около 45\% представителей этой возрастной группы ставили лайки понравившимся материалам о политических 
событиях, каждый четвертый обсуждал политические события и проблемы, давал им комментарии и оценки. От $14 \%$ до $16 \%$ представителей молодежи участвовали в электронных голосованиях и делали репосты наиболее интересных политических материалов. 12,2\% респондентов собирали подписи в поддержку каких-либо акций, включая протестные; около 6\% оказывали материальную поддержку политикам и их проектам. Доля молодежи, которая ведет блоги на политические темы, организовывает волонтеров для участия в политических акциях или сбора средств в политических целях, не превышает $3 \%$.

Ставили лайки понравившимся материалам о политических событиях 44,6

Обсуждали, давали комментарии и оценки различным политическим $\quad 23,5$ событиям и проблемам

Участвовали в голосовании на выборах (референдумах) в случае 16,3 возможности электронного голосования

Делали репосты наиболее интересных политических материалов

Участвовали в сборе подписей для поддержки каких-либо акций, включая протестные

Оказывали материальную поддержку политикам, их проектам

Вели блог на политические темы

Занимались организацией волонтеров для участия в политических акциях

Организовывали сбор средств в политических целях

2,0

Таблица 5. Политическая интернет-активность молодежи мегаполисов за последний год (\%). Вопрос: «Какие действия Bbl сами предпринимали за последние 2-3 года (Отметьте все варианты, соответствующие Вашему мнению)»

\section{ДИСКУССИЯ. ЭКСПЕРТНЫЕ ОЦЕНКИ ОСОБЕННОСТЕЙ ПОЛИТИЧЕСКОЙ ОНЛАЙН-КОММУНИКАЦИИ МОЛОДЕЖИ}

Интерес молодежи к политической тематике, по мнению ряда экспертов, крайне ограничен. Эффективная политическая коммуникация в Интернете должна быть связана с «производством события». 
Необходима острая актуальная новость, способная привлечь внимание именно молодежной аудитории, которая распространяется в Сети с помощью масс медиа или «инфлюенсеров, которые выполняют, по большому счёту, ровно эту роль» (ж., докт. полит. наук, доцент). По мнению экспертов, это может быть как общественно значимое событие, но может быть и

«какая-то версия геймификации, т.е. вроде бь ничего серьезного ... какое-то модное явление, которое вдруг пришло к какому-то человеку, который продумывает стратегию политической коммуникации, вокруг этого выстраивается какой-то нарратив, который обладает притягательностью для молодежной аудитории» (м., канд. полит. наук, активист парламентской оппозиционной партии).

Чтобы распространение информации шло эффективно, необходимо максимально органичное встраивание ее в повестку дня «инфлюенсеров» и средств массовой коммуникации; информация не должна выглядеть как продукт пропаганды или политическая реклама. На следующем этапе, если контент становится вирусным, копируется рядовыми пользователями социальных сетей, мессенджеров или интернет-каналов, он начинает распространяться с высокой скоростью

(«они уже друг другу начинают это показывать ... дальше начинается этап креативного обсуждения, возникновение всяких мемов. Это уже становится частью культуры» (м., канд. полит. наук, активист парламентской оппозиционной партии)).

Кроме того, срабатывает еще один механизм привлечения внимания молодежи к политической тематике за счет создания неформальных групп по типу клубов по интересам. Молодежи очень важно осознание единства с кем-то, разделяющим взгляды.

«Сейчас это стадия некого взросления, роста. Люди активно пытаются нащупать каких-то единомышиенников, причём, как правило, это происходит не на базе каких-то оформившихся политических организаций. Как правило, это происходит на уровне какой-то самоорганизачии. Это могут быть чаты в Telegram, это могут быть группь там ВКонтакте ... люди просто нащупывают друг друга чуть ли не слепую, потом объединяются, вместе участвуют в каких-то акциях, подтаскивают каких-то друзей, знакомых ... зачастую, не являясь членами каких-то конкретных организачий, не исповедуя каких-то конкретных взглядов, кроме общего недовольства существующей ситуацией, существующим политическим режимом» (м., представитель региональной власти). 
Социальные сети выполняют очень важную функцию политической идентификации, создавая если не иллюзию защищенности во время публичных массовых акций, то «чувство локтя» и сопричастности к какому-то делу, которое поддерживается очень многими людьми. Такое ощущение исключительно важно для принятия решения о включении в массовые мероприятия, которые субъективно воспринимаются как несущие риск для их участников. Например, «акция с фонариками» (начало февраля 2021 г.) не получила большой поддержки, но она рассматривается экспертами как отработка технологии «передачи эстафеты», сведения о которой распространяются через открытые группы.

«Bот, например, вчера ... эта акция с фонариками была. Примерно когда в 20:00 наступает условно в Новосибирске, Владивостоке, они уже потихонечку начинают разогревать. Вот столько людей вышли там, фоточки, вот столько людей вышли в Свердловске, там вот столько людей... потихонечку по стране они вон там вышли, там вышли, значит и мы здесь тоже выходuм» (м., активист оппозиционной парламентской партии).

Среди части молодежи весьма популярным является сочетание онлайн- и офлайн-просветительства на политические темы, особенно если в основе предлагаемых материалов лежат либеральные или либертарианские идеи; для позитивного восприятия информации достаточно актуален эффект новизны идеологического посыла. Если материалы выкладываются, например, на YouTube, то максимизируется возможность их обсуждения.

«Сейчас достаточно популярны псевдо-образовательные кружки, в которых люди выступают с лекциями, читают. Как раз вот молодежь туда приходит, они обсуждают все эти моменты» (м., специалист в области политических интернет-технологий).

Молодежь очень позитивно реагирует на новации, которые предоставляет эпоха глобализации и открытого информационного пространства.

«Не только молодежь, а вообще люди, которые широко представлены в Интернете, они живут с западным обществом в одной плоскости. У них общий культурный багаж. Отсюда и популярность тех же самых комиксов. Фильмы Marvel имеют такой успех у нас здесь в России не случайно, эта культура комиксов и культура фильмов, с ними связанных, она формирует некое культурное пространство... мы слушаем западную музыку, смотрим западные фильмы и читаем западную литературу. И если комиксы популарны там, они в какой-то момент станут популярны здесь» (м., специалист в области политических интернет-технологий). 
Попытки представителей политических институтов, государственной власти прийти на «территорию» социальных сетей, влиться в молодежные сообщества или хотя бы привлечь внимание этой части аудитории в большинстве случаев обречены на неудачу.

«Почему министерство иностранных дел в общем это очень плохой пример для Tik Tok или даже для YouТиbe? Оно не может начать разговор с молодежью с темы о каком-нибудь рэпере, как это делал Юрий Дудь. А они начинают сразу же вещать о своей повестке дня. Нет, если ты пришел на чужую, на самом деле, территорию и пытаешвся мимикрировать под этих молодых людей, то ты должен говорить на какую-то тему, которая в этой аудитории востребована» (м., канд. полит. наук, активист парламентской оппозиционной партии).

Неприятие значительной частью молодежи точки зрения представителей государственной власти не обязательно связано с политической оппозиционностью этой социально-демографической группы.

«Молодёжь, она по природе критик и отрицатель того, что ей было вложено в головы в детском возрасте. Она пытается от этого уйти, пытается отказаться, пытается показать себя, что она отличающаяся от всех других поколений, что они такие вот совершенно новые и никогда до них ничего подобного не было. Им это очень важно показать» (м., канд. полит. наук, активист парламентской оппозиционной партии).

Единственный шанс для представителей власти (институционализированных политических акторов) обратить на себя внимание молодежи - это показать себя экспертом в той области, которая интересна данной группе. Объективно при всех блестящих навыках молодежи оперативно получать нужную информацию далеко не у всех ее представителей уровень социальных и политических знаний является высоким, равно как и способность к системному пониманию социальных и политически процессов. Еще один путь для системных политиков привлечь уважительное и хотя бы относительно длительное по времени внимание молодежи - это попытаться добиться расположения кого-либо из популярных «инфблюенсеров», представляющих референтные группы для молодежи.

«Здесь не имеет смысл скупать, потому что это всегда будет выглядеть достаточно коряво. Нужно просто добиться того, чтобы быть среди них, чтобы общаться с ними на равных» (м., канд. полит. наук, активист парламентской оппозиционной партии).

Выбор социальных сетей, платформ, мессенджеров определяется комфортностью трансляции политической информации для потенци- 
ального потребителя; минимизация текстовых данных, использование видеообразов, ориентированных на эмоциональную реакцию, и возможность передачи сведений одновременно нескольким людям для обсуждения в группе являются основанием для выбора канала коммуникации онлайн.

«Им важно, чтобы сервис был удобным, чтобы была возможность для общения, для пересылки картинок, видео, демотиваторов» (м., политтехнолог); «Читать сейчас никто не готов. Потребляется визуальный или аудиовизуальный контент» (м., политический аналитик).

Существенное значение для молодежи при выборе площадки политической онлайн-коммуникации имеет ощущение безопасности, чувство защищенности, когда каждый может высказывать свою негативную точку зрения по политической проблематике даже в предельно грубой форме без риска быть наказанным, попасть «под статью» и т. д.

«Важную роль в предпочтениях каналов коммуникачии в интернет-пространстве играет то, как видят уровень контроля со стороны государства за этими каналами. Там, где молодёжь представляет себе, что контроль ниже, есть больше анонимности, меньше цензуры и больше свободы, там она вот проявляется более активно ... содержание этой коммуникации носит такой критиканский, негативныцй характер» (ж., докт. полит. наук, доцент).

Хорошие возможности политической коммуникации для молодежи предоставляют мессенджеры - чаты в WhatsApp и Telegram. Однако совершенных каналов связи нет, и этот тезис в полной мере относится к WhatsApp («Знаете, чего WhatsApp не может делать? Он длинный видеофайл не посылает, только фрагментами» (ж., докт. полит. наук, профессор)).

Эксперты отмечают высокую вероятность введения в случае роста протестных настроений запретительных мер, ограничивающих возможность использования многих мессенджеров и социальных сетей.

«Государство может что-то заблокировать, мыже понимаем, что идет к тому, что если в какой-то момент начнётся там жесть, условно говоря, то какие-то инструменты будут заблокированы. Значит, будут использованы альтернативные инструменты, те, которые не успеют или будут не готовы их заблокировать» (м., политтехнолог).

Попытки власти несколько лет назад ограничить использование Telegram не увенчались успехом, но в настоящее время изменившаяся 
стратегия в отношении этого мессенджера привела к тому, «что сегодня ниша политическая Telegram ... контролируется властью в первую очередь» (м., политтехнолог). Однако функция «люди рядом» может быть эффективно использована во время массовых акций.

«Делают чат и они уже вместе, всё знают, что они как бы вот участники этой акции, они присоединены, являются ячейкой, определенной ячейкой общего сообщества» (м., политтехнолог).

Некоторые эксперты, представляющие партию парламентского меньшинства, отмечают приверженность к этому мессенджеру несистемной оппозиции, однако считают такую коммуникацию не слишком эффективной, не имеющей практического выхода.

«Почему-то очень любят "Телегу” все наши новоявленные оппозиционеры. Вот, там они прямо коммуницируют, их хлебом не корми ... 40-50 сообщений ... Вот, видимо, хочется им пообсуждать, как бы другого выплеска нет, кроме как в «Тележку» написать» (м., активист оппозиционной парламентской партии)).

Ho Telegram высокоэффективен при передаче оперативной информации о практических действиях в публичном пространстве.

«Если мы сейчас говорим про организащию митинга, то "Телега". ... очень хорошо работает. Взять хотя бы митинг 31 числа, все ждали, что будет на Невском. Буквально за час они меняют место, и уже к ТЮЗу прибегает тысячи полторы человек. Я считаю, что это очень серьёзный мобилизующий инструмент» (м., активист оппозиционной парламентской партии).

Facebook воспринимается экспертами как площадка для взаимодействия людей среднего возраста с определенными статусными позициями, которая не очень интересна для молодежи («Facebook остаётся площадкой для городского среднего класса» (м., политтехнолог)).

В предельном случае, когда целевой группой является молодежь с «клиповым» сознанием, утратившая способность к чтению «mолстых фолиантов» и концентрации своего внимания более 2-3 минут, необходим формат, предлагаемый Tik Tok («всё теперь надо выкладывать в Tik Tok» (ж., докт. полит. наук, профессор)).

Впрочем, оценки экспертов перспектив Tik Tok в политической коммуникации очень разнятся. С одной стороны, эта площадка удобна для организации «челленджей», прежде всего оппозиционного характера.

«Один из челленджей заключался в том, что различные авторы контента в Tik Tok переодевались в какую-то форму а-ля государственную, например 
форму полищейского, и рвали паспорт. Не настоящий, естественно, они печатали обложку и как бы показательно её разрывали. Один из механизмов Tik Tok - это какой-то танеи, под определенную музыку. Тебе показывают движение, ты его повторяешь. Это один из главных механизмов в принципе Tik Tok» (м., специалист в области политических интернет-технологий).

Однако все, что построено на механическом повторении, «хайпе», «работает» только до того момента, пока не возникает какая-либо угроза безопасности индивида.

«Tik Tok показал свою неэффективность и больше использоваться не будет ... Этого мероприятия закончилось тем, что все, кто принимал 6 этом участие, в том или ином виде были задержаны, нам потом показывали в публичном поле видеоролики, как они на камеру извиняются ... Tik Tok больше в политический протест вовлечен не будет» (м., специалист в области политических интернет-технологий).

Мнения экспертов относительно возможностей использования Instagram для политической коммуникации с молодежью также разделились. С одной стороны, были высказаны высокие оценки этой сети («Любая политическая пропаганда ничем не отличается с точки зрения каналов коммуникации от обычной рекламы. Грамотный технолог пойдет туда, где целевая аудитория. А целевая аудитория сидит в Instagram, главная площзадка сейчас это Instagram» (м., политический аналитик)). С другой стороны, при всей сохраняющейся популярности Instagram техническое ограничение - отсутствие возможности коллективной коммуникации - делает эту площадку малоэффективной для формирования устойчивой системы политических взглядов или онлайн-мобилизации («в Инстаграме нет групповых возможностей обсуждения чего-либо, то есть ты только сегментировано заходишь $\kappa$ каждому пользователю на страницу» (м., политтехнолог)).

Стратегия использования политическими акторами YouTube направлена в основном на доведение до аудитории определенной точки зрения без реальной возможности организации дискуссии.

«ҮоиТиве является инструментом ... пропаганды, инструментом ... односторонней коммуникации, потому что комментарии в YоuТube, большинство из них, пишут боты» (м., политтехнолог)). «Молодежь действительно на ҮоиТиве присутствует. Здесь есть определенные возможности для продвижения какого-то контента различными политическими акторами, есть различные механизмы для монетизации отдельных инфлюенсеров. Үоитиве среди тех социальных медиа, которые сейчас активны, и является наиболее оптимальной площадкой для использования в качестве инструмента пропаганды среди молодежи» (м., канд. полит. наук, активист парламентской оппозиционной партии). 
Более активное присутствие в ВКонтакте политтехнологов, работающих на органы государственной власти, определяется широтой молодежной аудитории этой сети, наличием в ней достаточно большого числа настроенных лоялистки и патриотически устойчивых групп (сообществ). Важным моментом популярности использования этой сети является техническая возможность целенаправленного распространения определенного политического контента и, что исключительно важно, прагматическая возможность показать выполненную работу в отчетах.

\begin{abstract}
«Проправительственным политтехнологам удобнее работать в ВКонтакте, потому что Контакт пропускает политический таргет, если правильно всё организовать и потому что ВКонтакте просто самая большая аудитория, если мы говорим про численность. Поэтому для отчётности и так далее гораздо проще представлять ВКонтакте. Ну и вообще на самом деле в ВКонтакте просто достаточно большая еще патриотическая аудитория, поэтому, когда мы работаем с провластными политтехнологами, то им Контакт, конечно, всегда кажется наиболее привлекательной площадкой» (м., специалист в области политических интернет-технологий).
\end{abstract}

Более перспективной и привлекательной коммуникативной технологией для молодежи, особенно настроенной оппозиционно, является использование Clubhouse. В этой социальной сети активно формируется весьма оппозиционная аудитория, что весьма привлекательно для части молодежи. B Clubhouse весьма своеобразный механизм попадания на площадку. Это можно сделать в настоящее время только с айфонов. Доступ в эту сеть возможен только по приглашениям. И если на площадке начинает проявлять активность персона, чьи взгляды не совпадают с позицией большинства, то она тут же исключается из этой социальной сети. Существует возможность блокировки нежелательных участников на основе голосования автоматически по количеству поданных жалоб.

«Сейчас аудитория в Клабхаусе уже сформировалась оппозищионная, она просто больше, чем провластная. Любого лидера общественного мнения со стороны провластной тусовки тут же блокируют. Оппозиционные товарищи объединяются, массово жалуются на страничку определенного человека, страничка автоматически блокируется. Это произошло уже с двумя крупными инфлюенсерами - Сергеем Минаевым и Владимиром Соловьёвым ... Маргариту Симоньян там, скорее всего, тоже забанят. Даже если ей дадут приглашение, как только она попытается быть на площадке публичной персоной, а не просто присутствовать, то это сразу вызовет ответную реакцию. Они все объединяются, идут жаловаться, всё, тебя исключают» (м., специалист в области политических интернет-технологий). 
Преимущество Clubhouse заключается в том, что коммуникация голосовая, она не записывается. Эксперты считают, что в настоящее время это очень удачный инструмент для координации действий несистемной оппозиции.

«Это могло бы быть эффективной площадкой для координации протестов. Выз заходите в комнату... некий чат, объединяетесь в комнате. Допустим, у нас есть Леонид Волков, который сейчас сидит где-то в Прибалтике. Он организатор этой комнаты, к нему добавляются, допустим, 10 координаторов от Фонда борьбы с коррупщией, он им голосом диктует, что делать. "Сейчас, значит, собираемся там-то там-то, двигаемся туда-то туда-то" и так далее. Это никуда не записывается, представителей провластных сообществ в Clubhouse сейчас мало. То, что произнесено голосом, сложно, например, заскриншотить. Чтобы записать, что он говорит, вам нужно будет включить именно диктофон на телефоне, записать это, потом сделать расшифровку, и так далее. В общем, это очень сильно усложняет процесс, при котором их будут выяялять, использовать каким-то образом в судах и так далее. Скриншот сделать не получится, нужно именно записать ... Нужно же ещё и сидеть, и слушать всё это время. И это уже не считая того, что помимо того, что нужно попасть в эту закрытую комнату, нужно ещё и в само приложение попасть» (м., специалист в области политических интернет-технологий).

Один из парадоксов использования интернет-площадок для политической коммуникации с целью влияния на массовые общественные взгляды молодежи заключается в том, что явно политизированные каналы не могут быть безусловно популярными у значительной части этой возрастной группы.

«Чем больше эта площадка будет популярна у молодежи, тем меньше там будет политики. Facebook - это пространство политики, "Живой журнал" - это пространство политики, но это не то, ито популярно у молодёжи. По Яндекс-Дзену занятно было бы посмотреть цифры. Он достаточно политизирован, да. Но не думаю, что он является каким-то модным феноменом у молодежи. Twitter, который политизирован, не популярен в принциие» (м., канд. полит. наук, активист парламентской оппозиционной партии).

\section{РЕЗУЛЬТАТЫ ИССЛЕДОВАНИЯ}

Метод триангуляции данных (в классическом варианте он был предложен Д. Кемпбеллом), основанный на использовании двух независимых источников с целью получения максимально полной, достоверной и убедительной информации (в нашем случае это были данные онлайн-опроса и экспертного опроса) позволили получить корректную информацию о предпочтительных каналах и способах 
политической онлайн-коммуникации молодежи российских мегаполисов.

Пребывание свыше 4 часов в интернет-пространстве четырех пятых от общего числа молодежи делает очевидным значимость социальных сетей, интернет-каналов и мессенджеров не только в качестве источника информации, но и средств политической коммуникации и онлайн-мобилизации. Именно эти институты в современном мире выполняют важную роль агента вторичной политической социализации и ресоциализации молодежи.

Наиболее перспективными для политической коммуникации этой возрастной группы остаются ВКонтакте, Instagram, YouTube, WhatsApp и Telegram, определенные перспективы есть у Tik Tok и Clubhouse.

Политическая тематика и обсуждение сопутствующих проблем актуальны примерно для $22 \%$ молодых жителей российских мегаполисов. Четверть молодых жителей городов-миллионников в интернетпространстве не предпринимают вообе никаких действий, связанных с политикой. До 45\% реагируют с помощью эмодзи на материалы, посвященные политической тематике, но более активные действия, связанные с обсуждением таких тем, совершает лишь каждый пятый.

При этом для экспертов очевидны как относительно высокий интерес к политической тематике лишь части молодежи, так и неплохие возможности использования социальных сетей и мессенджеров для эффективной политической коммуникации внутри этой возрастной группы.

Соблазн политических акторов каким-то образом присутствовать на любой новой интернет-площадке с целью оказания влияния на молодежь понятен, но далеко не всегда оправдан. Минимальное условие быть услышанными этой весьма специфической аудиторией - быть как бы «одним из них», но при этом иметь не только притязания, но и право быть экспертом в глазах молодежи. Необходимо понимать, что явная демонстрация иных, а тем более противоположных им взглядов сразу ставит блокировку на восприятии информации этой группой. Для большинства «взрослых» политических акторов просто невозможно говорить на том же языке, что и молодежь, «играть по ее правилам».

Важным моментом формирования в интернет-пространстве площадок политической коммуникации молодежи является запрос на солидаризацию, попытка найти «таких же, как я», связанная прежде всего с некими аффективными явлениями, эмоциями. Далеко не 
всегда интернет-сообщества, позиционирующие себя как политические, стремятся рационально обсудить политические проблемы, открыть какие-то истины. С этой точки зрения, в молодежной среде более востребованы идеи популистского характера, подчас не очень содержательные, но обязательно содержащие элементы рационального, логического объяснения при общей весьма эмоционально манере выражения. Достаточно часто задачей «горячего» политического обсуждения является лишь потребность проявить свою эмоциональную реакцию по какому-либо политическому поводу или убедиться в том, что другие люди разделяют определенную точку зрения. Еще одним важным механизмом сплочения молодежных политических интернет-сообществ в социальных сетях и мессенджерах, хотя эта возрастная группа оценивается экспертами как более толерантная в политическом отношении, чем представители старших возрастных когорт, является стремление найти некое меньшинство думающих иначе и немедленно «здесь и сейчас» осудить тех, кто имеет смелость не соглашаться с большинством.

\section{БЛАГОДАРНОСТИ}

Исследование выполнено при финансовой поддержке РФФИ и ЭИСИ в рамках научного проекта № 20-011-31753 «Молодежь мегаполисов как социальная основа публичного протеста: предпосылки, технологии, формы, риски и эффекты политической онлайн-мобилизации».

\section{Список литературы}

Barbera, P., Casas, A., \& Nagler, J. (2019). Who Leads? Who Follows? Measuring Issue Attention and Agenda Setting by Legislators and the Mass Public Using Social Media Data. American Political Science Review, 113(4), 883-901. doi: 10.1017/ S0 003055419000352

Contucci, P., Omicini, A., Pianini, D., \& Sîrbu., A. (Eds.). (2019). The Future of Digital Democracy: An Interdisciplinary Approach. Cham: Springer. doi: 10.1007/978-3-030-05333-8

Davis, R. (2009). Typing Politics: The Role of Blogs in American Politics. Oxford; New York: Oxford University Press.

Deth, J. W. van. (2014). A Conceptual Map of Political Participation. Acta Politica, 49(3), 349367. doi: $10.1057 / a p .2014 .6$

Dijk, J. van. (2013). The network society: Social Aspects of New Media. London: SAGE Publications Ltd.

Evans, V. (2017). The Emoji Code: How Smiley Faces, Love Hearts and Thumbs up Are Changing the Way We Communicate. London: Michael O’Mara Books. 
Gleason, B. (2013). Occupy Wall Street: Exploring Informal Learning About a Social Movement on Twitter. American Behavioral Scientist, 57(7), 966-982. doi: $10.1177 / 0002764213479372$

Klandermans, P. G. (2014). Identity politics and politicized identities: Identity processes and the dynamics of protest. Political Psychology, 35(1), 1-22. doi: 10.1111/pops.12167

Theocharis, Y. (2015). The Conceptualization of Digital Networked Participation. Social Media + Society, 1(2), 1-14. doi: 10.1177/2056305115610 140

Авзалова, Э. И. (2020). Механизм политической мобилизации в сети Интернет. Вопросы начиональных и федеративных отношений, 10(12), 2866-2871. doi: 10.35775/PSI.2020.69.12.016

Ачкасова, В. А., \& Мельник, Г. С. (Ред.) (2016). Коммуникативные технологии в процессах политической мобилизации. Москва: ФЛИНТА: Наука.

Безрукова, Е. Ю. (2020). Социально-политический протест в России, или «Почему люди не бунтуют?» Власть, (2), 58-62. doi: 10.31171/vlast.v28i2.7135

Бродовская, Е. В., Домбровская, А. Ю., \& Синяков, А. В. (2015). Политическая субъектность пользователей социальных сетей в России: Результаты всероссийского социологического исследования. Вестник МГГУ им. М.А. Шолохова. История и политология, (2), 80-87.

Быков, И. А. (2013). Сетевая политическая коммуникация: Теория, практика и методь исследования. Санкт-Петербург: Издательство ФГБОУ ВПО «СПГУТД».

Володенков, С. В., \& Артамонова, Ю. Д. (2020). Информационные капсулы как структурный компонент современной политической интернет-коммуникации. Вестник Томского государственного университета. Философия. Социология. Политология, (53), 188-196. doi: 10.17223/1998863

Дзялошинский, И. М. (2012). Коммуникативное воздействие: Мишени, стратегии, технологии. Москва: НИУ ВШЭ.

Добринская, Д. Е. (2018). Киберпространство: Территория современной жизни. Becmник Московского университета. Серия 18. Социология и политология, (1), 52-70. doi: 10.24290/1029-3736-2018-24-1-52-70

Исакова, И. А., \& Коротышев, А. П. (2018). Политический постинг в современном рунете: Возможности и риски. Вестник Московского государственного областного университета, (4), 41-55. doi: 10.18384/2224-0209-2018-4-924

Истягина-Елисеева, Е. А., Бариеникова, Е. Е., \& Болдырева, А. В. (2020). Включенность российской студенческой молодежи в интернет-коммуникации как фактор формирования моделей их социально-политической активности. Цифровая сочиология, 3(3), 12-20. doi: 10.26425/2658-347X-2020-3-3-12-20

Малькевич, А. А. (2020). Роль социальных сетей в протестном политическом участии граждан. Управленческое консультирование, 1(133), 35-42. doi: 10.22394/17261139-2020-1-35-42

Михайленок, О. М. (2019). Информационно-коммуникативные риски сетевизации политических отношений. Вестник Института социологии, 10(3), 12-21. doi: 10.19181/vis.2019.30.3.584 
Палагичева, А. В. (2019). Технологии политической демобилизации граждан в протестных кампаниях. Среднерусский вестник общественных наук, (1), 218-231. doi: 10.22394/2071-2367-2019-14-1-218-231

Рябченко, Н. А., Катермина, В. В., Гнедаш, А. А., \& Малышева, О. П. (2018). Политический контент социальных движений в online-пространстве современных государств: Методология анализа и исследовательская практика. Южно-российский журнал социальных наук, (3), 139-162. doi: 10.31429/26 190 567-19-3-139-162

Соколов, А. В., \& Палагичева, А. В. (2020). Мобилизация и демобилизация в сетевом политическом протесте. Политическая наука, (3), 266-297. doi: 10.31249/poln/ 2019.03.12

Хвыля-Олинтер, Н. А. (2016). Интернет-фактор в ценностном развитии молодежи России. Alma таter. Вестник высшей школь, (5), 104-109.

Шаповалова, И. С. (2015). Влияние интернет-коммуникаций на поведение и интеллектуальное развитие молодежи. Социологические исследования, (4), 148-151.

Юй, С. (2021). Использование социальных сетей в политической коммуникации. Политическая лингвистика, (85), 149-158. doi: 10.12345/1999-2629_2021_01_14.

\section{References}

Barbera, P., Casas, A., \& Nagler, J. (2019). Who Leads? Who Follows? Measuring Issue Attention and Agenda Setting by Legislators and the Mass Public Using Social Media Data. American Political Science Review, 113(4), 883-901. doi: 10.1017/ S0 003055419000352

Contucci, P., Omicini, A., Pianini, D., \& Sîrbu., A. (Eds.). (2019). The Future of Digital Democracy: An Interdisciplinary Approach. Cham: Springer. doi: 10.1007/978-3-030-05333-8

Davis, R. (2009). Typing Politics: The Role of Blogs in American Politics. Oxford; New York: Oxford University Press.

Deth, J. W. van. (2014). A Conceptual Map of Political Participation. Acta Politica, 49(3), 349367. doi: $10.1057 /$ ap.2014.6

Dijk, J. van. (2013). The network society: Social Aspects of New Media. London: SAGE Publications Ltd.

Evans, V. (2017). The Emoji Code: How Smiley Faces, Love Hearts and Thumbs up Are Changing the Way We Communicate. London: Michael O'Mara Books.

Gleason, B. (2013). Occupy Wall Street: Exploring Informal Learning About a Social Movement on Twitter. American Behavioral Scientist, 57(7), 966-982. doi: $10.1177 / 0002764213479372$

Klandermans, P. G. (2014). Identity politics and politicized identities: Identity processes and the dynamics of protest. Political Psychology, 35(1), 1-22. doi: 10.1111/pops.12167

Theocharis, Y. (2015). The Conceptualization of Digital Networked Participation. Social Media + Society, 1(2), 1-14. doi: 10.1177/2056305115610 140 
Avzalova, E. I. (2020). The mechanism of political mobilization on the Internet. Questions of national and federal relations, 10(12), 2866-2871. doi: 10.35775/PSI.2020.69.12.016 (In Russian).

Achkasova,V. A., \& Melnik, G. S. (Eds.) (2016). Communication technologies in the processes of political mobilization. Moscow: FLINTA: Nauka. (In Russian).

Bezrukova, E. Yu. (2020). Socio-Political Protest in Russia or “Why Don't People Rebel”?. Власть, (2), 58-62. doi: 10.31171/vlast.v28i2.7135 (In Russian).

Brodovskaya, Ye. V., Dombrovskaya, A. Yu., \& Sinyakov, A. V. (2015). Political subjectivity of social network users in Russia: results of nationwide sociological study. Bulletin of the Moscow State Humanitarian University named after M.A. Sholokhov. History and Political Science, (2), 80-87. (In Russian).

Bykov, I. A. (2013). Network political communication: Theory, practice, and research methods. St. Petersburg: SPGUTD. (In Russian).

Volodenkov, S. V., \& Artamonova, Yu. D. (2020). Information Capsules as a Structural Component of Modern Political Internet Communication. Bulletin of Tomsk State University. Philosophy. Sociology. Political science, (53), 188-196. doi: 10.17223/1 998863 (In Russian).

Dzyaloshinskij, I. M. (2012). Communication Impact: Targets, Strategies, Technologies. Moscow: HSE. (In Russian).

Dobrinskaya, D. E. (2018). Cyberspace: the Territory of Modern Life. Moscow University Bulletin. Series 18. Sociology and Political Science, (1), 52-70. doi: 10.24290/1029-37362018-24-1-52-70 (In Russian).

Isakova, I. A., \& Korotyshev, A. P. (2018). Political Posting in the Modern Runet: Opportunities and Risks. Bulletin of the Moscow State Regional University, (4), 41-55. doi: 10.18384/2224-0209-2018-4-924 (In Russian).

Istyagina-Yeliseeva, E. A., Barijenikova, C. E., \& Boldyreva, A. V. (2020). Involvement of Russian Student Youth in Internet Communications as a Factor in the Formation of Models of Their Socio-Political Activity. Digital sociology, 3(3), 12-20. doi: 10.26425/2658-347X-2020-3-3-12-20 (In Russian).

Malkevich, A. A. (2020). The Role of Social Media in Protest Political Participation of Citizens. Administrative Consulting, 1(133), 35-42. doi: 10.22394/1726-1139-2020-1-35-42 (In Russian).

Mikhailenok, O. M. (2019). Information and Communication Risks of the Networking of Political Relations. Bulletin of the Institute of Sociology, 10(3), 12-21. doi: 10.19181/ vis.2019.30.3.584 (In Russian).

Palagicheva, A. V. (2019). Technologies of Political Demobilization of Citizens in Protest Campaigns. Central Russian fournal of Social Sciences, (1), 218-231. doi: 10.22394/2071-2367-2019-14-1-218-231 (In Russian).

Ryabchenko, N. A., Katermina, V. V., Gnedash, A. A., \& Malysheva, O. P. (2018). Political content of social movements in the online space of modern states: methodology of analysis and research practice. South Russian fournal of Social Sciences, (3), 139-162. doi: 10.31429/26 190 567-19-3-139-162 (In Russian). 
Sokolov, A. V., \& Palagicheva, A. V. (2020). Mobilization and Demobilization in a Network Political Protest. Political science, (3), 266-297. doi: 10.31249/poln/2019.03.12 (In Russian).

Hvylya-Olinter, N. A. (2016). Internet Factor in the Value Development of Russian Youth. Alma mater. Higher school bulletin, (5), 104-109. (In Russian).

Shapovalova, I. S. (2015). The Impact of Internet Communications on the Behavior and Intellectual Development of Young People. Sociological research, (4), 148-151. (In Russian).

Yu, X. (2021). The Use of Social Networking Sites in Political Communication. Political Linguistics, (85), 149-158. doi: 10.12345/1999-2629_2021_01_14 (In Russian). 